\title{
Basal and insulin stimulated substrate metabolism in tumour induced hypoglycaemia; evidence for increased muscle glucose uptake
}

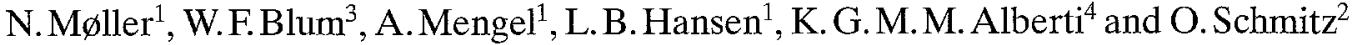 \\ 1 2nd University Clinic of Internal Medicine, Aarhus Kommunehospital, ${ }^{2}$ University Clinic of Endocrinology and Internal Medicine, \\ Aarhus Amtssygehus, Aarhus, Denmark, ${ }^{3}$ Universitäts-Kinderklinik, Tübingen, FRG, and ${ }^{4}$ Department of Medicine, \\ The Medical School, Newcastle Upon Tyne, UK
}

Summary. While it has very recently been reported that tumour induced hypoglycaemia is characterised by elevated production of insulin-like growth factor 2 , the tissues responsible for induction of hypoglycaemia are largely unknown. We have investigated a patient with a large retroperitoneal mass and spontaneous hypoglycaemia. When compared to a reference population the patient displayed: (1) An increased glucose disposal rate and a five-fold elevation of forearm glucose uptake. (2) A decreased endogenous glucose production rate. (3) Decreased circulating levels of lipid intermediates. (4) Increased glucose oxidation and decreased lipid oxidation. (5) Low circulating levels of insulin-like growth factor 2 and insulin-like growth factor-binding protein- 3 and normal levels of insulin-like growth factor 1. (6) Normal insulin sensitivity (euglycaemic glucose clamp). Blood concentrations of insulin, C-peptide, proinsulin, glucagon, growth hormone and catecholamines were within normal range, but the growth hormone response to hypoglycaemia was blunted. The data suggest that the mechanisms behind tumour induced hypoglycaemia are of systemic nature and that the tissue most prominently affected is striated muscle.

Key words: Glucose turnover, forearm technique, intermediary metabolites, euglycaemic and hypoglycaemic glucose clamp, indirect calorimetry.
Since non-Beta-cell tumour induced hypoglycaemia was described in 1930 [1] the pathogenesis of this rare condition has remained enigmatic. There is no evidence that insulin is the mediator of hypoglycaemia [2,3], but very recently convincing data have suggested that insulin-like growth factor 2 is the precipitating factor in many cases [ 4 , 5].

It is still not clear which tissues are responsible for the induction of hypoglycaemia. Theoretically a decrease in plasma glucose concentration could result from either a decrease in endogenous (hepatic) glucose production or an increase in peripheral glucose utilisation. Case reports [6-8] have suggested that overall glucose turnover may be increased in tumour induced hypoglycaemia, but have not provided information as to whether this increase resides in tumour tissue or elsewhere. Striated muscle is the tissue capable of increasing glucose utilisation quantitatively most significantly. We report of a patient with tumour induced hypoglycaemia in whom endogenous glucose production, peripheral glucose utilisation, muscle glucose uptake and fuel oxidation have been quantitated in the basal and in the insulin stimulated state.

\section{Subjects and methods}

A 63-year-old man was hospitalized in the University Clinic following three weeks of episodes of reversible sweating, confusion, stupour and quadriplegia in the postabsorptive state. Symptoms were relieved by ingestion of carbohydrates.

Six years earlier the patient was diagnosed as having malignant melanoma of the right retina, which was surgically removed.

On admission the patient's weight was $80.5 \mathrm{~kg}$ and height $183 \mathrm{~cm}$. Physical examination showed a large mass situated deeply between the umbilicus and the pubic crest.

Blood glucose measured during three of the above episodes was between 0.9 and $2.1 \mathrm{mmol} / 1$. Other routine laboratory measurements, including liver function tests, were within normal range. Ultrasound of the abdomen showed a rounded retroperitoneal mass with a diameter of $15 \mathrm{~cm}$, which was judged inoperable. Needle biopsy showed sarcoma or malignant melanoma tissue; staining with antibody HMB-45 antibody (melanoma associated) was negative. Computerised tomographic and ultrasound scans showed no signs of cerebral or liver metastases respectively. Fasting serum insulin was 12.5 and $12.5 \mathrm{mU} /$ (normal range: $0.0-25$ ), plasma C-peptide 0.06 and $0.06 \mathrm{nmol} / 1$ (normal range: $0.18-0.63$ ) and proinsulin 8.2 and $9.7 \mathrm{pmol} / 1$ during hypoglycaemia $(2.9 \mathrm{mmol} / \mathrm{l})$ and normoglycaemia $(5.5 \mathrm{mmol} / 1)$ respectively.

The patient continued to suffer from episodes of spontaneous hypoglycaemia throughout and in the postabsorptive state i.v. glucose 
had to be administered. Treatment with a somatostatin analogue (Sandostatin) for six days (200 $\mu \mathrm{g} / 24 \mathrm{~h}$ continously s.c.) was attempted with no effect on the requirement for exogenous glucose or circulating levels of insulin-like growth factors. The patient died five months after admission.

\section{Methods}

Following a $10 \mathrm{~h}$ fast the patient was investigated on two occasions: (1) During a $3 \mathrm{~h}$ sequential euglycaemic/hypoglycaemic hyperinsulinaemic glucose clamp (i.e. $2 \mathrm{~h}$ normoglycaemia $(5 \mathrm{mmol} / \mathrm{l})$ followed by 1 h hypoglycaemia $(2.5 \mathrm{mmol} / \mathrm{l})$ preceded by a $2 \mathrm{~h}$ "basal" period and (2) In the "basal" state for $2 \mathrm{~h}$. The design of the two "basal" state experiments was identical. Both investigations were carried out at 08.00 hours and following an $10 \mathrm{~h}$ infusion of glucose to maintain normoglycaemia (i.e. 4-6 $\mathrm{mmol} / \mathrm{l}$ ); to avoid counterregulation in the "basal" state this infusion was continued based on 5-min plasma glucose measurements. At 07.30 hours one catheter was placed retrogradely in a heated dorsal hand vein for sampling of arterialised blood and another catheter was positioned anterogradely into an antecubital vein for infusions.

On both occasions glucose turnover was measured employing a constant $(30 \mu \mathrm{Ci} / \mathrm{h})$ primed $(30 \mu \mathrm{Ci}) \mathrm{i}$. v. infusion of 3 -3H-glucose (DuPont/NEN, Boston, Mass., USA) as described previously [9]. The isotope was allowed to equilibrate for $2 \mathrm{~h}$. The equation of Steele et al., as modified by DeBodo [10] was used for calculation of non-steady state glucose appearance $(\mathrm{Ra})$ and disposal rates $(\mathrm{Rd})$. A pool fraction of 0.65 was used.

During the glucose clamp human insulin (Actrapid, Novo, Bagsvaerd, Denmark) was infused i.v. at a rate of $1 \mathrm{mU} \cdot \mathrm{kg}^{-1} \cdot \mathrm{min}^{-1} 2 \mathrm{~h}$ after introduction of 3-3H-glucose. Based on 5 min measurements of plasma glucose an i. v. infusion of $20 \%$ glucose was continuously adjusted to maintain normoglycaemia. During glucose infusion endogenous glucose production was assessed by subtracting the amount of exogenous glucose (M-value) from the isotopically determined Ra.

In the "basal state" study forearm glucose uptake was measured [11]. Briefly, a catheter was inserted retrogradely in a deep antecubital vein and ipsilateral forearm blood flow was measured by mercury in rubber strain gauge venous occlusion plethysmography.

In both studies oxygen consumption and carbon dioxide production was measured for $30 \mathrm{~min}$ employing a computerised indirect calorimeter (Deltatrac, Datex Instruments Inc., Helsinki, Finland) [12]. Serum insulin and growth hormone $(\mathrm{GH})$ and plasma glucagon were radioimmunoassayed [13], as was plasma adrenaline and noradrenaline [14]. Serum C-peptide was measured in a commercial kit (Immunonuclear Corp., Stillwater, MN, USA). Insulin-like growth factor 1 (IGF 1) and 2 (IGF 2) were determined by radioimmunoassay after acid-ethanol extraction [15-17]. The GH dependent IGFbinding protein (IGF-BP-3) was measured in unextracted serum employing an antibody against the acid-stable subunit (IGF-BP-3ß) [18].

Blood lactate, alanine, 3-hydroxybutyrate and glycerol were assayed by enzymatic centrifugal analysis [19]. Serum non-esterified fatty acids (NEFA) were measured by a radio-cobalt method [20]. On all occasions plasma glucose was measured in dublicate immediately after sampling (Beckman Instruments, Palo Alto, Calif.,
USA). All hormones assayed, glucose turnover and forearm glucose uptake were measured in at least triplicate over a $30 \mathrm{~min}$ period as mentioned. Unless specified otherwise all blood samples referred to below were drawn from arterialised blood.

The reference values are derived from the following populations of healthy normal weight persons studied under conditions identical to those above (apart from the glucose infusion to maintain normoglycaemia in the basal state): (1) Basal state studies: 11 male subjects aged $33 \pm 5$ years. (2) Euglycaemic hyperinsuliaemic clamp: 10 male subjects aged $42 \pm 4$ years. (3) IGF 1 , IGF 2 and IGF-BP-3: 19 subjects aged $65 \pm 1$ years. Before the studies were initiated informed consent were obtained from the participants and the protocols were approved by the local ethical commitee.

\section{Statistical analysis}

Reference values (Ref) given below are mean $\pm S E M$; since values for IGF 1, IGF 2 and IGF-BP-3 were $\log$-normal distributed these parameters are expressed as 5 th, 50 th and 95 th percentile.

\section{Results}

\section{Basal state (Table 1)}

In the "basal state" study and during the $2 \mathrm{~h}$ period preceding the glucose clamp the following results were obtained: Serum insulin concentration was stable at 12 and $15 \mathrm{mU} / 1$, serum C-peptide at 0.30 and $0.23 \mathrm{nmol} / 1$, serum $\mathrm{GH}$ at 0.8 and $0.5 \mu \mathrm{g} / 1$ and plasma glucagon at 11 and $18 \mathrm{ng} / \mathrm{l}$, plasma adrenaline at 50 and $85 \mathrm{pg} / \mathrm{ml}$ and noradrenaline at 610 and $700 \mathrm{pg} / \mathrm{ml}$. Circulating concentrations of IGF 1 were between 111 and $123 \mathrm{ng} / \mathrm{ml}$ (ref: 5th: 37,50 th: 71 and 95 th percentile: $144 \mathrm{ng} / \mathrm{ml}$ ), IGF 2 between 323 and $350 \mathrm{ng} / \mathrm{ml}$ (ref: 5 th: 355,50 th: 542 and 95 th percentile: $828 \mathrm{ng} / \mathrm{ml}$ ) and IGF-BP-3 between 1285 and $1418 \mathrm{ng} / \mathrm{ml}$ (ref: 5 th: 1889,50 th: 2979 and 95 th percentile: $4978 \mathrm{ng} / \mathrm{ml})$.

Plasma glucose concentrations were "clamped" at 5.0 and $4.9 \mathrm{mmol} / 1$ by infusion of exogenous glucose. During the last $30 \mathrm{~min}$ of the two studies in the postabsorptive state 3.1 and $4.7 \mathrm{mg} \cdot \mathrm{kg}^{-1} \cdot \mathrm{min}^{-1}$ was infused.

Isotopical determination of $\mathrm{Rd}$ and $\mathrm{Ra}$ yielded steady state levels of 4.3 and $5.2 \mathrm{mg} \cdot \mathrm{kg}^{-1} \cdot \mathrm{min}^{-1}$ (Ref Rd: $\left.2.3 \pm 0.1 \mathrm{mg} \cdot \mathrm{kg}^{-1} \cdot \mathrm{min}^{-1}\right)$ and 4.3 and $5.3 \mathrm{mg} \cdot \mathrm{kg}^{-1} \cdot \mathrm{min}^{-1}$ (Ref Ra: $2.3 \pm 0.1 \mathrm{mg} \cdot \mathrm{kg}^{-1} \cdot \mathrm{min}^{-1}$ ) respectively. Derived values for endogenous glucose production are 1.2 and $0.6 \mathrm{mg} \cdot \mathrm{kg}^{-1} \cdot \mathrm{min}^{-1}\left(\mathrm{Ref} \mathrm{Ra}: 2.3 \pm 0.1 \mathrm{mg} \cdot \mathrm{kg}^{-1} \cdot \mathrm{min}^{-1}\right)$.

Total forearm bloodflow was $2.8 \mathrm{ml} \cdot 100 \mathrm{ml}^{-1} \cdot \mathrm{min}^{-1}$ (Ref: $2.6 \pm 0.2 \mathrm{ml} \cdot 100 \mathrm{ml}^{-1} \cdot \mathrm{min}^{-1}$ ) and skin temperature on the unheated forearm $30.5^{\circ} \mathrm{C}$ (Ref: $30.2 \pm 0.2^{\circ} \mathrm{C}$ ). Oxygen tensions in arterialised and deep venous blood

Table 1. Circulating values of IGF 1, IGF 2, IGF-binding protein-3, exogenous glucose administration (M-val.), rate of appearance for glucose (Ra), endogenous glucose production (EGP) and forearm glucose uptake (FGU) during the two "basal" state studies (NN) as compared to a relevant reference population (Ref. pop.)

\begin{tabular}{|c|c|c|c|c|c|c|c|}
\hline & $\begin{array}{l}\mathrm{IGF1} \\
\mathrm{ng} / \mathrm{ml} \mathrm{l}\end{array}$ & $\begin{array}{l}\mathrm{IGF2} \\
\mathrm{ng} / \mathrm{ml}\end{array}$ & $\begin{array}{l}\text { IGF-BP-3 } \\
\mathrm{ng} / \mathrm{ml}\end{array}$ & $\begin{array}{l}\text { M-val. } \\
\mathrm{mg} \cdot \mathrm{kg}^{-1} \cdot \mathrm{min}^{-1}\end{array}$ & $\begin{array}{l}\mathrm{Ra} \\
\mathrm{mg} \cdot \mathrm{kg}^{-1} \cdot \mathrm{min}^{-1}\end{array}$ & $\begin{array}{l}\mathrm{EGP} \\
\mathrm{mg} \cdot \mathrm{kg}^{-1} \cdot \mathrm{min}^{-1}\end{array}$ & $\begin{array}{l}\mathrm{FGU} \\
\mathrm{mg} \cdot 100 \mathrm{ml}^{-1} \cdot \mathrm{min}^{-1}\end{array}$ \\
\hline$\overline{\mathrm{NN}}$ & $\begin{array}{l}111 \\
123\end{array}$ & $\begin{array}{l}323 \\
350\end{array}$ & $\begin{array}{l}1285 \\
1418\end{array}$ & $\begin{array}{l}3.1 \\
4.7\end{array}$ & $\begin{array}{l}4.3 \\
5.2\end{array}$ & $\begin{array}{l}1.2 \\
0.6\end{array}$ & 0.47 \\
\hline $\begin{array}{l}\text { Ref. } \\
\text { pop. }\end{array}$ & 71 & 542 & 2979 & 0 & $\begin{array}{l}2.3 \pm \\
0.1\end{array}$ & $\begin{array}{l}2.3 \pm \\
0.1\end{array}$ & $\begin{array}{l}0.10 \pm \\
0.01\end{array}$ \\
\hline
\end{tabular}


Table 2. Recorded values for exogenous glucose administration (Mval.), rate of appearance for glucose (Ra) and exogenous glucose production (EGP) during hyperinsulinaemic glucose clamps of a patient with tumour induced hypoglycaemia (NN) and of a reference population (Ref. pop.)

\begin{tabular}{lcll}
\hline & $\begin{array}{c}\text { M-val. } \\
\mathrm{mg} \cdot \mathrm{kg}^{-1} \cdot \mathrm{min}^{-1}\end{array}$ & $\begin{array}{l}\mathrm{Ra} \\
\mathrm{mg} \cdot \mathrm{kg}^{-1} \cdot \mathrm{min}^{-1}\end{array}$ & $\begin{array}{l}\mathrm{EGP} \\
\mathrm{mg} \cdot \mathrm{kg}^{-1} \cdot \mathrm{min}^{-1}\end{array}$ \\
\hline $\mathrm{NN}$ & 9.9 & 7.9 & -2.0 \\
Ref. & $10.3 \pm$ & $8.6 \pm$ & $-1.7 \pm$ \\
pop. & 0.5 & 0.4 & 0.4 \\
\hline
\end{tabular}

was within normal range. Calculated basal forearm glucose uptake was $0.47 \mathrm{mg} \cdot 100 \mathrm{ml}^{-1} \cdot \mathrm{min}^{-1}$ (Ref: $\left.0.10 \pm 0.01 \mathrm{mg} \cdot 100 \mathrm{ml}^{-1} \cdot \mathrm{min}^{-1}\right)$.

Circulating levels of NEFA were $315 \mu \mathrm{mol} / \mathrm{l}, 3$-hydroxybutyrate $5 \mu \mathrm{mol} / 1$, glycerol $15 \mu \mathrm{mol} / 1$, lactate $705 \mu \mathrm{mol} / 1$ and alanine $120 \mu \mathrm{mol} / 1$. Energy expenditure (EE) was $2040 \mathrm{kcal} / 24 \mathrm{~h}$ (Ref: $1892 \pm 29 \mathrm{kcal} / 24 \mathrm{~h})$ and nonprotein respiratory exchange ratio (RER) was 0.89 (Ref: $0.79 \pm 0.01)$ and derived values for fuel oxidation $0.6 \mathrm{mg} \cdot \mathrm{kg}^{-1} \cdot \mathrm{min}^{-1}$ (fat) (Ref: $1.3 \pm 0.1 \mathrm{mg} \cdot \mathrm{kg}^{-1} \cdot \mathrm{min}^{-1}$ ) and $2.4 \mathrm{mg} \cdot \mathrm{kg}^{-1} \cdot \mathrm{min}^{-1}$ (glucose) (Ref: $1.2 \pm 0.1 \mathrm{mg}$. $\mathrm{kg}^{-1} \cdot \min ^{-1}$ ) leading to a non-oxidative glucose turnover of $3.8 \mathrm{mg} \cdot \mathrm{kg}^{-1} \cdot \mathrm{min}^{-1}$ (Ref: $1.1 \pm 0.1 \mathrm{mg} \cdot \mathrm{kg}^{-1} \cdot \mathrm{min}^{-1}$ ).

\section{Hyperinsulinaemic clamp (Table 2)}

After the induction of hyperinsulinaemia serum insulin concentration increased from a pre-level of $12 \mathrm{mU} / \mathrm{l}$ to a plateau of $55 \mathrm{mU} / 1$ during both normo- and hypoglycaemia. Serum C-peptide decreased slightly from 0.30 to $0.20 \mathrm{nmol} / \mathrm{l}$. Plasma glucagon remained at a concentration of $12 \mathrm{ng} / \mathrm{l}$ during euglycaemia and increased to $37 \mathrm{ng} / \mathrm{l}$ during hypoglycaemia. Serum GH stayed at the baseline level of $1.3 \mu \mathrm{g} / \mathrm{l}$ regardless of the prevailing plasma glucose (hypoglycaemia: $1.0 \mu \mathrm{g} / 1$ ). Plasma adrenaline and noradrenaline concentrations were not affected by hyperinsulinaemia alone, but increased to values of 420 and $1150 \mathrm{pg} / \mathrm{ml}$ respectively during hypoglycaemia.

During euglycaemia plasma glucose was stable at $93 \mathrm{mg} / 100 \mathrm{ml}$ and $30 \mathrm{~min}$ after induction of hypoglycaemia relatively stable at $44-53 \mathrm{mg} / \mathrm{ml}$. Maintenance of euglycaemia required $9.9 \mathrm{mg} \cdot \mathrm{kg}^{-1} \cdot \mathrm{min}^{-1}$ (Ref: $10.3 \pm$ $\left.0.5 \mathrm{mg} \cdot \mathrm{kg}^{-1} \cdot \mathrm{min}^{-1}\right)$ and hypoglycaemia $5.2 \mathrm{mg} \cdot \mathrm{kg}^{-1}$. $\mathrm{min}^{-1}$ exogenously administered glucose. Corresponding turnover values $(\mathrm{Ra})$ were 7.9 (Ref: $8.6 \pm 0.4 \mathrm{mg} \cdot \mathrm{kg}^{-1}$. $\mathrm{min}^{-1}$ ) and $5.7 \mathrm{mg} \cdot \mathrm{kg}^{-1} \cdot \mathrm{min}^{-1}$. During euglycaemia calculated endogenous glucose production thus was $2.0 \mathrm{mg} \cdot \mathrm{kg}^{-1} \cdot \mathrm{min}^{-1} \quad$ (Ref: $\quad-1.7 \pm 0.4 \mathrm{mg} \cdot \mathrm{kg}^{-1} \cdot \mathrm{min}^{-1}$ ) and during hypoglycaemia $0.5 \mathrm{mg} \cdot \mathrm{kg}^{-1} \cdot \mathrm{min}^{-1}$.

\section{Discussion}

The present study was undertaken to elucidate the mechanisms leading to pertubation of metabolic homeostasis in tumour induced hypoglycaemia. Earlier case reports have suggested increased glucose turnover in this condition [68]. These reports are however prior to the "clamp era" and it is possible that infusion of fixed amounts of glucose (to prevent hypoglycaemia) may have induced slight hyperglycaemia and -insulinaemia leading to increases in total glucose turnover and decreases in endogenous glucose production. Since recorded glucose turnover was increased by a factor of 2-3 under conditions of well controlled normoglycaemia and normolinsulinaemia our results clearly suggest that overutilisation of glucose is pivotal to the development of hypoglycaemia. As would be expected the increase in total glucose turnover was accompanied by increased glucose oxidation. This effect has also been noted earlier [8].

The observed $50 \%$ reduction in endogenous glucose production may contribute to the development of hypoglycaemia, but quantitatively not to the same extent as the inapproprate elevation of glucose utilisation. The role of striated muscle in the exaggerated disposal of glucose in tumour induced hypoglycaemia has, to our knowledge, not been well described previously. When compared to normal control subjects the patient in question displayed a forearm glucose uptake that was elevated by a factor of five. Assuming that all blood drawn from the deep forearm vein is muscle derived and that a $70 \mathrm{~kg}$ man has $30 \mathrm{~kg}$ of muscle metabolically similar to forearm muscle a forearm glucose uptake of $0.47 \mathrm{mg} \cdot 100 \mathrm{ml}^{-1} \cdot \mathrm{min}^{-1}$ would extrapolate to $2.0 \mathrm{mg} \cdot \mathrm{min}^{-1} \cdot \mathrm{kg}^{-1}$ total body mass leaving $2.3 \mathrm{mg} \cdot \mathrm{kg}^{-1} \cdot \mathrm{min}^{-1}$ for other tissues including tumour tissue. In agreement with other studies [7] we found considerably suppressed levels of all circulating lipid intermediates, indicating inhibition of lipolysis.

The coexistence of increased muscle glucose uptake, decreased hepatic glucose production and inhibition of lipolysis does not seem compatible with isolated local metabolic derangement in tumour tissue, but speaks strongly in favour of a humoral agent with insulin-like activity being causative. It has been argued that since circulating levels of insulin in tumour induced hypoglycaemia have been within normal range these pertubations are not mediated by insulin. It is, however, well known that in many disease states tissue sensitivity to the metabolic actions of insulin may be substantially impaired or increased. The present finding of normal insulin sensitivity as judged by a hyperinsulinaemic euglycaemic clamp does not provide any evidence that hypersensitivity to insulin is of pathogenic importance for tumour induced hypoglycaemia. Furthermore, the intact glucagon and catecholamine responses to hypoglycaemia with subsequent appropriate adjustments of glucose metabolism does not point to any primary defect in counterregulation. Recently strong evidence that tumour induced hypoglycaemia is associated with increased tumour production of IGF 2 has been reported [ 4 , 5]. In the present study, as in others, circulating levels of neither IGF 1 nor IGF 2 seemed elevated. It is nevertheless puzzling that serum concentrations of IGF-BP-3 appeared to be reduced. The low concentration of binding protein and the following decreased binding capacity could perhaps lead to increased concentrations of metabolically highly active unbound IGF 1 and 2 .

Alternatively, molecular forms of IGF with metabolic activity, but with low affinity for the antibody employed, may have been present in the circulation. The absence of 
any $\mathrm{GH}$ response during hypoglycaemia also speaks in favour of disturbances of the feedback inhibition of IGF 1 and 2 on GH secretion; furthermore, production of IGF binding protein, a process which is GH dependent [21], could be suppressed by lack of GH influence.

In summary, we have found evidence that tumour induced hypoglycaemia is associated with increased total glucose disposal, increased glucose oxidation, increased muscle glucose uptake, reduced endogenous glucose production, inhibited lipolysis and normal insulin sensitivity. These insulin-like effects cannot solely be due to local metabolic derangement of the tumour.

\section{References}

1. Doege KW (1930) Fibro-sarcoma of the mediastinum. Ann Surg 92: 955-960

2. Unger RH (1966) The riddle of tumor induced hypoglycemia. Am J Med 40:325-330

3. Kahn CR (1980) The riddle of tumor induced hypoglycemia revisited. Clin Endocrinol Metab 9: 335-360

4. Daughaday WH, Emanuelle MA, Brooks MH, Barbato AL, Kapidia M, Rotwein P (1988) Synthesis and secretion of insulinlike growth factor II by a leiomyosarcoma with associated hypoglycemia. N Engl J Med 319: 1434-1440

5. Ron D, Powers AC, Pandian MR, Godine JE, Axelrod L (1989) Increased insulin-like growth factor II production and consequent suppression of growth hormone secretion: a dual mechanism for tumor induced hypoglycemia. J Clin Endocrinol Metab 68: 701-706

6. Volpe R, Evans J, Clarke D, Forbath N, Ehrlich R (1965) Evidence favoring the sarcomatous origin of an insulin-like substance in a case of fibrosarcoma with hypoglycemia. Am J Med 38: $540-553$

7. Jacob A, Meyer U, Flury R, Ziegler WH, Labhart A, Froesch ER (1965) The pathogenesis of tumor induced hypoglycemia: blocks of hepatic glucose release and of adipose tissue lipolysis. Diabetologia 3:506-514

8. Kreisberg RA, Hershman JM, Spenney JG, Boshell BR, Pennington LF (1970) Biochemistry of extrapancreatic tumor hypoglycemia. Diabetes 19: 248-258

9. Hother-Nielsen O, Schmitz O, Bak J, Beck-Nielsen H (1987) Enhanced hepatic insulin sensitivity, but peripheral insulin resistance in patients with type 1 (insulin dependent) diabetes. Diabetologia 30: 834-840

10. DeBodo RC, Steele R, Altszuler N, Dunn A, Bishop JS (1963) On the hormonal regulation of carbohydrate metabolism: studies with C14-glucose. Recent Prog Horm Res 19: 445- 488
11. Møller N, Butler PC, Antsiferov MA, Alberti KGMM (1989) Effects of growth hormone on insulin sensitivity and forearm metabolism in normal man. Diabetologia 32: 105-110

12. Møller N, Jørgensen JOL, Alberti KGMM, Flyvbjerg A, Schmitz O (1990) Short-term effects of growth hormone on fuel oxidation and regional substrate metabolism in normal man. J Clin Endocrinol Metab 70: 1179-1186

13. Ørskov H, Thomsen HG, Yde H (1968) Wick-chromatography for rapid and reliable immunoassay of insulin, glucagon and growth hormone. Nature 219: 193-195

14. Eriksson BM, Persson BA (1982) Determination of catecholamines in rat heart tissue and plasma samples by liquid chromatography with electrochemical detection. J Chromatogr 228: 143-154

15. Daughaday WH, Parker KA, Borowsky S, Trivedi B, Kapadia M (1982) Measurement of somatomedin-related peptides in fetal, neonatal and maternal rat serum by insulin-like growth factor (IGF) I radioimmunoassay, IGF-II radioreceptor assay (RRA) and multiplicationstimulating activity RRA after acidethanol extraction. Endocrinology 110:575-581

16. Blum WF, Ranke MB, Bierich JR (1986) Isolation and partial characterisation of six somatomedin-like peptides from human plasma Cohn fraction IV. Acta Endocrinol 111:271-284

17. Blum WF, Ranke MB, Bierich JR (1988) A specific radioimmunoassay for insulin-like growth factor II: the interference of IGF binding proteins can be blocked by excess IGF-I. Acta Endocrinol 118: 374-380

18. Blum WF, Ranke MB, Kietzman K, Gauggel E, Zeisel HJ, Bierich JR (1990) A specific radioimmunoassay for the growth hormone dependent somatomedin binding protein: its use for diagnosis of growth hormone deficiency. J Clin Endocrinol Metab 70: $1292-1295$

19. Harrison J, Hodson AW, Skill AW, Stappenbeck R, Agius L, Alberti KGMM (1988) Blood glucose, lactate, pyruvate, glycerol, 3-hydroxybutyrate and acetoacetate measurements in man using a centrifugal analyser with a flurimetric attachment. J Clin Chem Clin Biochem 26: 141-146

20. Ho RJ, Meng HC (1969) A simple and ultrasensitive method for determination of free fatty acids by radiochemical assay. Ann Biochem 31: 426-430

21. White RM, Nisley SP, Moses AC, Rechler MM, Johnsonbaugh RE (1981) The growth hormone dependence of a somatomedinbinding protein in human serum. J Clin Endocrinol Metab 53: $49-57$

Received: 22 February 1990

and in revised form: 14 May 1990

Dr. N. Møller

Med. Afd. M

Aarhus Kommunehospital

DK-8000 Aarhus C

Denmark 